\title{
Enhancing forest productivity through afforestation on arid salt affected sandy soils in Rajasthan
}

Ranjana Arya \& RR Lohara

Arid Forest Research Institute, P.O. Krishi Mandi, New Pali Road, Jodhpur 342 005, India

$\checkmark$ Corresponding author: R Arya, e-mail: rarya@icfre.org

Copyright (C2016 Arya \& Lohara, This is an open access article published under the terms of the Creative Commons Attribution License, which permits unrestricted use, distribution, and reproduction in any medium, provided the original work is properly cited.

Preferred citation for this article: Arya R \& Lohara RR. 2016. Enhancing forest productivity through afforestation on arid salt affected sandy soils in Rajasthan. Journal of Agriculture and Ecology, 1: 59-70; http://doi.org/10.53911/JAE.2016.1107.

\begin{abstract}
.Abstract
Soil salinity/alkalinity is an important factor adversely affecting soil health and plant productivity on arid salt affected soils. In India, $6.73 \mathrm{~m}$ ha area has been reported to be salt affected of which about $50 \%$ (2.98 m ha) occurs in Rajasthan, Gujarat, Haryana and Punjab. Utilization of these salt affected areas has become necessary owing to increasing need for fodder and fuel wood for rural poor but they require specific approaches for their reclamation. Experimental trials were conducted on lithic, calcid, coarse sandy to loamy sand salt affected soil in Jodhpur, Rajasthan to find out suitable exotic and indigenous plant species and planting practice to increase the production. Results on performances of various tree and shrub species with management practices showed that Salvadora persica (L) a preferential halophyte, evergreen multipurpose indigenous tree proved most versatile with 85.2 to $66.7 \%$, survival in different treatments at 72 months of age . Effect of treatments was positive and $\mathrm{T}_{6}$ (gypsum $+9 \mathrm{~g} \mathrm{~N}$ ) was the best treatment attaining $207 \mathrm{~cm}$ of height and 212 $\mathrm{cm}$ of crown diameter, which was $38 \%$ and $24 \%$ more than the untreated plants. It produced $12.0 \mathrm{~kg} /$ tree of above ground biomass followed by $10.7 \mathrm{~kg}$ and $8.8 \mathrm{~kg}$ in $\mathrm{T}_{8}(\mathrm{gyp}+27 \mathrm{~g} \mathrm{~N}$ ) and $\mathrm{T}_{2}(9 \mathrm{~g} \mathrm{~N})$ respectively which was $71 \%, 53 \% \& 27 \%$ more than the control (untreated plants). There is no decrease in survival even after 18 years. In another experimental set up tree species like Sueada nudiflora, Atriplex lentiformis and Atriplex stocksii performed well on different types of mound techniques i.e. Double ridge mound (DRM) and Circular dished mound (CDM). Based on survival and growth $S$. nudiflora was the best species followed by A. lentiformis and A.stocksii. Overall DRM was the best planting practice producing maximum mean dry biomass. C. mopane (Kirk et Benth), an exotic species of south central Africa, maintained $89 \%$ overall mean survival after five years and plants on CDM structure attained $113 \& 158 \mathrm{~cm}$ as mean height and crown diameter respectively as compared to 101 $\& 151 \mathrm{~cm}$ for control at 60 months of age. Overall plants on CDM recorded a mean $1.45 \mathrm{~kg}$ green biomass yield/plant which is $5.9 \%$ more compared to control $(1.37 \mathrm{~kg})$.
\end{abstract}


Key Words: Salt affected, arid, survival, biomass, gypsum, nitrogen, mound practices

\section{Introduction}

Salinity is the major abiotic stress, which severely affects crop yields. It is more acute in the arid and semi-arid regions of the world. In India, $6.73 \mathrm{~m}$ ha area has been reported to be salt affected of which about $50 \%$ (2.98 m ha) occurs in the states of Rajasthan, Gujarat, Haryana and Punjab (Sharma 2004). Paucity of fresh water discourages reclamation of salty lands. Appropriate tree species and planting methods can help rehabilitation of arid salty areas that are characterized by low rainfall, high evapo-transpiration demands, highly saline ground waters and calcareous sub-soils. The population pressure is also very high and agricultural lands fail to fulfill the food, feed, fodder and industrial raw material needs. Therefore, it is necessary to exploit plants species that can perform on these soils. Salvadora persica (L), popularly known as Miswak, toothbrush tree or khara jal stores excess salts in mature and senescent leaves and in the bark, is a salt tolerant indigenous tree species on arid salt affected lands in India, particularly in Rajasthan, Gujarat, Punjab and Western Uttar Pradesh (Amonkar \& Karmakar 1978). Literature revealed that C. mopane (Kirk et Benth), a multipurpose glycophytic xeric species of savanna woodland zone of south central Africa (Lock 1989) grows in hot, dry, low-lying areas, and also in alkaline (high lime content) soils which are shallow and not well drained (Bennet1983). Their performance was studied with gypsum and nitrogen. Atriplex shrubs have been recognized for their high productivity, tolerance to saline sodic soils and production of quality forage material. They tolerate high levels of salt in soil and water and resist low and high environmental temperatures and droughts (Pasternak et al. 1986; Uchiyama 1987). A. lentiformis (exotic )and A. stocksii, halophytic salt bushes and Sueada nudiflora, succulent halophyte were established and produced nitrogen rich fodder on arid salty waterlogged soil in Jodhpur. Mounding practices significantly enhanced the survival, growth and biomass production for both the species. The highlights of their performances are discussed here.

\section{Materials and Methods}

Field trials were laid on a hummocky, sandy plain with a shallow, hard and compact substratum that is impervious to roots and water at Gangani, Jodhpur. The soil of the experimental site was classified as a lithic, calcid, coarse sandy to loamy sand, underlaid by a thick hard pan of calcium carbonate to a depth of $25-100 \mathrm{~cm}$. The soil $\mathrm{pH}$ ranged from 8.2 to 9.8 and EC from 4.2 to $16 \mathrm{~d} \mathrm{Sm}^{-1}$. The exchangeable sodium percentage ranged from 30-60 $\%$. The organic carbon content ranged from 0.1 to $0.2 \%$. The soil was poor in nitrogen and phosphorus with a gypsum requirement of $6 \mathrm{tha}^{-1}$. The mean annual rainfall of the site was $350 \mathrm{~mm}$, which was mainly confined to the monsoon period (from July to September). The total number of rainy days during the year varied in between 8-17 days. The maximum temperature rise was as high as $50^{\circ} \mathrm{C}$ in summer and minimum was $4^{0} \mathrm{C}$ during winter. Average wind velocity in the summer months was 15 to $25 \mathrm{~km} \mathrm{~h}^{-1}$. The monthly rainfall during the entire study period from August 1997 to December 2008 is summarised in Table1 . 
Table 1. Monthly rainfall pattern during the study period beginning from August 1997 to December 2008

\begin{tabular}{lcccccccccccc}
\hline Month & & & \multicolumn{1}{c}{ Rainfall (mm) } \\
& 1997 & 1998 & 1999 & 2000 & 2001 & 2002 & 2003 & 2004 & 2005 & 2006 & 2007 & 2008 \\
\hline January & - & 0.0 & 006.0 & 0.5 & 0.0 & - & 0.7 & 0.0 & Traces & 0 & Trace & Trace \\
February & - & 3.8 & 014.2 & 0.0 & 0.0 & 0.7 & 23.8 & 0.0 & 004.0 & 0 & 22.0 & Trace \\
March & - & 14.0 & 000.0 & 2.5 & 0.0 & - & 2.7 & 0.0 & 000.3 & 0.8 & 29.1 & 1.6 \\
April & - & 36.0 & 000.0 & 5.0 & 0.0 & 4.7 & 0.0 & 0.2 & 005.3 & 6.0 & 14.8 & 24.6 \\
May & - & 0.0 & 011.7 & 19.3 & 33.9 & 0.6 & 0.4 & 0.0 & 023.3 & 0 & 1.0 & 91.4 \\
June & - & 163.0 & 048.5 & 214.1 & 53.5 & 7.7 & 64.6 & 31.5 & 014.1 & 21.0 & 22.3 & 97.5 \\
July & - & 56.7 & 058.6 & 46.4 & 203.6 & - & 260.3 & 35.1 & 132.9 & 27.7 & 73.4 & 66.2 \\
August & 201.1 & 105.3 & 138.6 & 3.0 & 113.7 & 13.8 & 65.3 & 139.5 & 077.2 & 185.5 & 73.2 & 138.8 \\
September & 42.8 & 52.4 & 007.8 & 1.5 & 10.6 & 11 & 1.6 & 11.1 & 025.9 & 29.2 & 83.7 & 13.8 \\
October & 47.7 & 47.3 & 010.7 & 0.5 & 14.6 & - & 0.0 & 2.8 & 000 & 0 & 0.0 & Trace \\
November & 0.0 & 0.0 & 000.0 & 0.5 & 0.0 & 0.6 & 0.0 & N.A. & 000 & 0 & 0.0 & 0.0 \\
December & 0.0 & 0.0 & 000.0 & 0.0 & & 11.5 & 0.0 & N.A. & 000 & 0.2 & 0.2 & 3.8 \\
\hline
\end{tabular}

Performance of $S$. persica with gypsum and nitrogen

The trial was laid out in September, 1997 using a factorial design with three replications, two levels of gypsum: Control $\left(\mathrm{G}_{0}\right)$ and Gypsum @ $100 \%$ soil $\mathrm{GR}\left(\mathrm{G}_{1}\right)$ and four nitrogen levels: $0 \mathrm{~g}\left(\mathrm{~N}_{0}\right), 9 \mathrm{~g}\left(\mathrm{~N}_{1}\right), 18 \mathrm{~g}\left(\mathrm{~N}_{2}\right)$, and $27 \mathrm{~g}\left(\mathrm{~N}_{3}\right)$ of $\mathrm{N}$ in the form of urea. There were 9 plants in every treatment at spacing of $3 \times 4 \mathrm{~m}$. The area was deep ploughed after the first spell of rain. Pits of $50 \times 50 \times 50 \mathrm{~cm}$ were dug and $3 \mathrm{~kg}$ farmyard manure (FYM), $15 \mathrm{~g}$ single super phosphate (SSP) and gypsum (according to treatment) was mixed with pit soil at the time of planting.

\section{Performance of $C$. mopane with gypsum and nitrogen}

The trial was laid in August 2003 with two levels of gypsum (0 and 100\% soil G.R.) and three doses of nitrogen $(0,9$ and $18 \mathrm{~g}$ of $\mathrm{N}$ in the form of urea) on two modes of planting, (control and circular dish mound- CDM) in a randomized block design. There were total eight treatment combinations with six plants per treatment. In a similar trial (Arya et al 2005) on S. persica (another indigenous tree species) it was observed that application of nitrogen in combination with gypsum (gypsum $+9 \mathrm{~g} \mathrm{~N}$ ) gave the best results, an increment of $41 \%$ for height and $35 \%$ for crown diameter over the untreated plants at the same site. CDM was prepared by raising soil to a height of $20 \mathrm{~cm}$ in a circle of $2 \mathrm{~m}$ diameter manually (Arya et al, 2006). Pits of $50 \times 50 \times 50 \mathrm{~cm}$ were dug and $3 \mathrm{~kg}$ farmyard manure (FYM), $15 \mathrm{~g}$ single super phosphate (SSP) and gypsum (according to treatment) was mixed with pit soil at the time of planting. Treatment wise urea application was done in Dec2003 with irrigation (40 lit/plant). As the species is glycophytic in nature, monthly supplemental irrigation was provided from Dec 2003- June 2004, Dec 2004- June 2005 and December 2005- June 2006. Urea application was repeated in January, 2006 in the nitrogen treatments. C. mopane showed deciduous nature (Motlhanka, 2008) in the third year of growth, shedding leaves in summer and re-sprouting after first rain. No irrigation was given after that. One weeding was carried out in October every year. $25 \%$ pruning was carried out in January 06 and mean $649.35 \mathrm{~g}$ green mass/treatment was recorded for the CDM compared to $443.7 \mathrm{~g}$ green mass /treatment for control.

Performance of shrub species on various types of mound 
The trial was laid in a Randomized Block Design in August 2000. Four replications of 6 plants each were planted for each species at spacing of 3 x $3 \mathrm{~m}$. Three $\mathrm{kg}$ FYM, $15 \mathrm{~g}$ SSP and gypsum at $100 \%$ soil GR was mixed with pit soil at the time of planting. Soil drenching with $0.2 \%$ chloropyriphos was also carried out.

For making double ridge mounds, bunds $(0.50 \mathrm{~m}$ broad and $0.45 \mathrm{~m}$ high) were constructed with the help of tractor and ridges (20 cm high) were made manually. Distance between two ridges (planting space) was $1.2 \mathrm{~m}$. Circular dished mounds were prepared by raising soil to a height of $20 \mathrm{~cm}$ in a circle of $2.0 \mathrm{~m}$ diameter manually. Monthly irrigation of 30 1/irrigation was given from September 2000 to May 2001 followed by irrigation in October and March to May, 2002. Due to complete monsoon failure, irrigation (25 lit/plant) was provided in August, October, November 2002, Jan and March-May2003 to save the plantations. One weeding was undertaken annually during October-November to remove weeds.

\section{Field observation}

Survival was recorded annually. Initial height was recorded immediately after planting. Further data on height, crown diameter and collar diameter were recorded annually in all the trials.

Biomass estimation: Component-wise biomass study was also carried out for all the three trials. Using the mean height and crown diameter, one average plant was selected from each treatment in each replication for S. persica (Trial-1), C. mopane (Trial- -2) and A. lentiformis, A. stocksii and S. nudiflora (Trial- 3). For S. persica one each of 8 treatments in three replications, thus a total of 24 trees were felled for biomass study in September 2003. Similarly for C. Mopane, a total of 24 plants, three in each of the eight treatment were felled for biomass study in August 2008. Component-wise biomass study was also carried out for all the three shrub species in August 2003 after attainment of 36 months. Using the mean heights and crown diameters as selection criteria, three average shrubs were selected for each of the three species for destructive sampling in all the three structures. Thus, a total of 27 shrubs, 9 from every species were cut for biomass study. Above ground biomass was estimated by cutting the tree/ shrub from the ground level and leaves and branches were separated to determine the fresh weight of each part of the tree. The representative samples were taken to laboratory for estimating oven dry biomass.

\section{Results and Discussion}

\section{Performance of S. persica with gypsum and nitrogen}

Survival and growth

Despite deficient rainfall conditions, appreciable survival ranging from 85.2 to $66.7 \%$ was recorded in different treatments (Table 2) with no effect of treatments. Results of sixth year of plant growth indicate that treatments in combination with gypsum gave better results as compared to application of nitrogen alone. $\mathrm{T}_{6}$ (gypsum $+9 \mathrm{~g} \mathrm{~N}$ ) was the best treatment attaining $207.0 \mathrm{~cm}$ of height and $212.0 \mathrm{~cm}$ of crown diameter. The results of analysis of variance showed that effect of gypsum application was nonsignificant on height ( $\mathrm{p}-0.07)$ and crown diameter (p-0.06) but was significant for collar girth (p-0.047). In case of collar girth, the overall mean of gypsum treated plants was $12.4 \%$ more than the untreated plants. Nitrogen application influenced only the height (p-0.05). LSD values indicate that in case of 
height, all the nitrogen levels $\left(\mathrm{N}_{1}-\mathrm{N}_{3}\right)$ recorded significantly higher height than $\mathrm{N}_{0}$ level, but the difference among them was not significant. For crown diameter, $\mathrm{N}_{1}$ nitrogen level recorded better crown diameter than control. Interaction of gypsum $\mathrm{x}$ nitrogen was significant for crown diameter and collar girth.

Table 2. Survival and growth (Mean \pm SE) of $S$. persica under various levels of gypsum and nitrogen after 72 months at Gangani, Jodhpur, Rajasthan

\begin{tabular}{lcccccccccc}
\hline Parameters & & & $\mathrm{G}_{0}$ & & & & & $\mathrm{G}_{1}$ & & \\
& $\mathrm{~N}_{0}$ & $\mathrm{~N}_{1}$ & $\mathrm{~N}_{2}$ & $\mathrm{~N}_{3}$ & Mean & $\mathrm{N}_{0}$ & $\mathrm{~N}_{1}$ & $\mathrm{~N}_{2}$ & $\mathrm{~N}_{3}$ & Mean \\
\hline \%Survival & 81.5 & 85.2 & 74.0 & 85.2 & 81.5 & 81.5 & 77.8 & 70.4 & 66.7 & 74.1 \\
& $(3.70)$ & $(3.70)$ & $(7.41)$ & $(3.70)$ & & $(3.70)$ & $(6.41)$ & $(9.79)$ & $(12.83)$ & \\
Height & 148.9 & 161.8 & 192.3 & 173.1 & 169.0 & 163.9 & 206.8 & 168.7 & 192.7 & 183.0 \\
& $(13.27)$ & $(3.88)$ & $(14.65)$ & $(10.68)$ & & $(11.66)$ & $(3.76)$ & $(11.13)$ & $(8.28)$ & \\
Crown & 171.3 & 172.4 & 195.8 & 172.7 & 178.1 & 171.3 & 212.1 & 171.5 & 204.5 & 189.9 \\
diameter & $(6.03)$ & $(4.85)$ & $(9.18)$ & $(11.51)$ & & $(10.08)$ & $(10.51)$ & $(3.32)$ & $(8.97)$ & \\
Collar girth & 19.38 & 20.02 & 24.80 & 18.43 & 20.6 & 21.4 & 26.12 & 20.6 & 24.7 & 23.2 \\
& $(1.04)$ & $(0.81)$ & $(3.61)$ & $(1.54)$ & & $(0.80)$ & $(0.52)$ & $(2.00)$ & $(0.41)$ & \\
\hline
\end{tabular}

Note: $\mathrm{G}_{0}$ (Control) and $\mathrm{G}_{1}\left(\mathrm{Gypsum} @ 100 \%\right.$ soil GR) ; $\left(\mathrm{N}_{0}: 0 \mathrm{~g}, \mathrm{~N}_{1}: 9 \mathrm{~g}, \mathrm{~N}_{2:} 18 \mathrm{~g}\right.$, and $\mathrm{N}_{3}$ : $27 \mathrm{~g}$ of $\mathrm{N}$ in the form of urea.

\section{Green Biomass}

The component wise green biomass yield is depicted in Table 3. The data indicates that the above ground green biomass was maximum in $\mathrm{T}_{6}$ treatment, $12.0 \mathrm{~kg} /$ tree followed by $10.7 \mathrm{~kg}$ and $8.8 \mathrm{~kg}$ in $\mathrm{T}_{8}(\mathrm{gyp}+27 \mathrm{~g} \mathrm{~N})$ and $\mathrm{T}_{2}(9 \mathrm{~g} \mathrm{~N})$ treatments, respectively. The results of analysis of variance showed that effect of gypsum application significantly influenced the green yield for leaf(p-0.05), branch $(\mathrm{p}-0.02)$, stem (0.010) and total biomass (p-0.013). It was due to 27.3, 32.3, 22.9 and $27.2 \%$ increase respectively over control for $\mathrm{N}_{0}-\mathrm{N}_{3}$ levels. Effect of various nitrogen treatments was highly significant for leaf, branch, stem and total. The yield was maximum at $\mathrm{N}_{1}$ level followed by $\mathrm{N}_{3}$ and $\mathrm{N}_{2}$ level for all the biomass components along with control recording the minimum yield. LSD values suggest that the entire treatments $\left(\mathrm{N}_{1}-\mathrm{N}_{3}\right.$ levels) recorded higher yield, however, the difference with control was significant for $\mathrm{N}_{1}$ and $\mathrm{N}_{3}$ levels only. The contribution of leaf component to total biomass ranged from 30.0-33.8 \% for different nitrogen levels in control while it was 29.5-34.5\% in gypsum treated plants. The maximum contribution was from stem component ranging from $36 \%$ in $\mathrm{N} 2$ level to $44 \%$ in $\mathrm{N}_{1}$ level.

Table 3. Green biomass yield of $S$. persica to various levels of gypsum and nitrogen after 72 months at Gangani, Jodhpur, Rajasthan

\begin{tabular}{lcccccccccc}
\hline Paramet & & \multicolumn{3}{c}{$\mathrm{G}_{0}$} & & & & & $\mathrm{G}_{1}$ & \\
ers & $\mathrm{N}_{0}$ & $\mathrm{~N}_{1}$ & $\mathrm{~N}_{2}$ & $\mathrm{~N}_{3}$ & Mean & $\mathrm{N}_{0}$ & $\mathrm{~N}_{1}$ & $\mathrm{~N}_{2}$ & $\mathrm{~N}_{3}$ & Mean \\
\hline Leaf & 2.12 & 2.64 & 2.46 & 2.58 & 2.45 & 2.72 & 3.54 & 2.73 & 3.49 & 3.12 \\
Branch & 1.93 & 2.61 & 2.18 & 2.07 & 2.2 & 2.35 & 3.17 & 2.57 & 3.56 & 2.91 \\
Stem & 2.51 & 3.53 & 2.65 & 2.67 & 2.84 & 2.8 & 5.30 & 2.77 & 3.79 & 3.49 \\
Total & 6.59 & 8.79 & 7.27 & 7.32 & 7.49 & 7.88 & 12.01 & 8.20 & 10.83 & 9.73 \\
LSD & Leaf & Branch & Stem & Total & & & & & & \\
$(0.05)$ & G: 0.68 & G:0.41 & G:0.4 & G:1.5 & & & & & & \\
& N:NS & N:NS & 7 & 3 & & & & & & \\
& & & N:0.6 & N:NS & & & & & & \\
\hline
\end{tabular}


Note: $\mathrm{G}_{0}$ (Control) and $\mathrm{G}_{1}$ (Gypsum @ $100 \%$ soil GR) ; $\left(\mathrm{N}_{0}: 0 \mathrm{~g}, \mathrm{~N}_{1}: 9 \mathrm{~g}, \mathrm{~N}_{2:} 18 \mathrm{~g}\right.$, and $\mathrm{N}_{3}$ : $27 \mathrm{~g}$ of $\mathrm{N}$ in the form of urea.

Survival of C. Mopane

C. mopane maintained appreciably high survival on arid salty soil and registered $96.7 \%$ mean survival on CDM and $91.2 \%$ in control after one year of planting. Similar survival was maintained during the 12-60 months of age and registered $92.0 \%$ survival on CDM and 86.5 $\%$ in control after five year of planting (Table-4).

Table 4. Performance of C.mopane on soil amelioration with gypsum and nitrogen

\begin{tabular}{|c|c|c|c|c|c|c|c|c|c|c|c|c|}
\hline \multirow[t]{4}{*}{ Treatment } & \multicolumn{6}{|c|}{ Control } & \multicolumn{6}{|c|}{$\mathrm{CDM}$} \\
\hline & \multicolumn{2}{|c|}{$\% \mathrm{~S}$} & \multicolumn{2}{|c|}{$\mathrm{Ht}(\mathrm{cm})$} & \multicolumn{2}{|c|}{ Crown dia } & \multicolumn{2}{|c|}{$\%$ Survival } & \multicolumn{2}{|c|}{$\mathrm{Ht}(\mathrm{cm})$} & \multicolumn{2}{|c|}{$\begin{array}{l}\text { Crown dia } \\
\quad(\mathrm{cm})\end{array}$} \\
\hline & \multicolumn{6}{|c|}{ Age in months } & \multicolumn{6}{|c|}{ Age in months } \\
\hline & $12 *$ & 60 & 12 & 60 & 12 & 60 & 12 & 60 & 12 & 60 & 12 & 60 \\
\hline $\mathrm{G}_{0} \mathrm{~N}_{\mathrm{O}}$ & 94.4 & 87.0 & 38.5 & 89.5 & 51.9 & 145.8 & 87 & 81.7 & 38.4 & 95.3 & 53.1 & 146.4 \\
\hline $\mathrm{G}_{1} \mathrm{~N}_{0}$ & 77.7 & 77.7 & 46.0 & 105.8 & 48.0 & 151.6 & 100 & 100 & 42.4 & 104.7 & 55.2 & 148.4 \\
\hline $\mathrm{G}_{1} \mathrm{~N}_{1}$ & 92.5 & 92.5 & 36.1 & 110.8 & 52.6 & 152.8 & 100 & 87 & 38.7 & 121.7 & 61.1 & 167.3 \\
\hline $\mathrm{G}_{1} \mathrm{~N}_{2}$ & 100 & 100 & 36.4 & 99.9 & 43.6 & 155 & 100 & 100 & 36.1 & 130 & 47.4 & 171.4 \\
\hline & 91.1 & 88.9 & 39.3 & 101.5 & 49.0 & 151.3 & 96.7 & 92.1 & 38.9 & 112.9 & 54.2 & 158.4 \\
\hline
\end{tabular}

*Age in month

Plant Growth

C. mopane showed shrubby nature and attained more mean crown diameter 40.0 and $54.2 \mathrm{~cm}$ as compared to mean height 38.9 and $39.3 \mathrm{~cm}$ on CDM and control treatments respectively, at 12 months of age. The mean height was $101.5 \mathrm{~cm}$ for control and $112.9 \mathrm{~cm}$ for CDM respectively at 60 months of age registering 2.58 and 2.90 times more height as compared to 12 months (Table 4). Treatments significantly influenced the height and the height difference between control $(92.3 \mathrm{~cm})$ and $\mathrm{T}_{3}\left(116.3 \mathrm{~cm}, \mathrm{~N}_{1}\right.$ dose) was significant (p 0.03). The mean crown diameter was $151.3 \mathrm{~cm}$ for control and $158.4 \mathrm{~cm}$ for CDM respectively at 60 months of age registering 3.09 and 2.92 times more crown diameter as compared to 12 months.

\section{Biomass production}

\section{Above ground}

Component-wise biomass values are summarized in Table 5. Plants recorded slightly higher biomass yield on CDM compared to control. Overall plants on CDM recorded a mean 1445.5 g green biomass yield plant ${ }^{-1}$ which was $5.9 \%$ more compared to control plants (1376 g). The difference was $9.1 \%$ for leaf and $5.2 \%$ for branch components respectively. A minimum of $1018.3 \mathrm{~g} /$ tree total yield was recorded for $\mathrm{T}_{1}$ treatment in control while a maximum of 1875.3 $\mathrm{g} /$ tree was observed under $\mathrm{N}_{2}$ dose on CDM structure. Data analysis showed that effect of structures was not significant, however treatments (p- 0.00) influenced the biomass yield and all the treatments recorded higher biomass compared to control. $\mathrm{CD}$ values exhibited that 
Gypsum alone $\left(\mathrm{T}_{2}\right)$ was not significantly high but combination of gypsum and nitrogen $\left(\mathrm{T}_{3} \&\right.$ $\mathrm{T}_{4}$ ) were significantly high both on CDM and control soil structures. (Table 5).

Table 5. Green biomass yield of $C$. mopane (Mean \pm SE) at five years of age under different treatments

\begin{tabular}{|c|c|c|c|c|c|c|}
\hline \multirow[t]{3}{*}{ Treatments } & \multicolumn{3}{|c|}{ Control } & \multicolumn{3}{|c|}{ CDM } \\
\hline & \multicolumn{6}{|c|}{$\operatorname{Green}\left(\mathrm{g}\right.$ tree $\left.^{-1}\right)$} \\
\hline & Leaf & Branch & Total & Leaf & Branch & Total \\
\hline \multirow[t]{2}{*}{$\mathrm{G}_{0}+\mathrm{N}_{0}$} & 440.0 & 578.3 & 1018.3 & 465.0 & 585.0 & 1050.0 \\
\hline & $(42.5)$ & $(17.4)$ & $(59.9)$ & $(65.0)$ & (31.2) & $(78.6)$ \\
\hline \multirow[t]{2}{*}{$\mathrm{G}_{1}+\mathrm{N}_{0}$} & 488.3 & 750.0 & 1238.3 & 535.0 & 621.6 & 1156.6 \\
\hline & $(22.4)$ & $(38.2)$ & $(60.6)$ & $(56.2)$ & $(60.6)$ & (108.6) \\
\hline \multirow[t]{2}{*}{$\mathrm{G}_{1}+\mathrm{N}_{1}(9 \mathrm{~g})$} & 746.6 & 978.3 & 1725.0 & 781.6 & 968.3 & 1750.0 \\
\hline & $(37.1)$ & $(77.5)$ & $(101.4)$ & $(20.5)$ & (118.3) & (137.6) \\
\hline \multirow[t]{2}{*}{$\mathrm{G}_{1}+\mathrm{N}_{2}(18 \mathrm{~g})$} & 590.0 & 933.3 & 1523.3 & 690.0 & 1135.3 & 1825.3 \\
\hline & (7.6) & $(58.3)$ & $(87.2)$ & $(35.0)$ & (59.0) & $(88.5)$ \\
\hline Mean & 566.2 & 810.0 & 1376.2 & 605.4 & 827.5 & 1445.5 \\
\hline \multirow[t]{2}{*}{$\mathrm{CD}(0.05)$} & \multicolumn{2}{|c|}{ St -63.20} & \multicolumn{2}{|c|}{$\mathrm{St}-100.03$} & \multicolumn{2}{|c|}{$\mathrm{St}-\mathrm{NS}$} \\
\hline & \multicolumn{2}{|c|}{ Treat -89.37} & \multicolumn{2}{|c|}{ Treat -141.47} & \multicolumn{2}{|c|}{ Treat -200.6} \\
\hline
\end{tabular}

Leaf yield

The green leaves yield ranged from a minimum of $440.0 \mathrm{~g}$ plant $^{-1}$ under control to a maximum of $781.6 \mathrm{~g}_{\text {plant }}{ }^{-1}$ in $\mathrm{T}_{3}$ treatment on CDM which was $77.6 \%$ more (Table 4). Plants on CDM recorded 4.7 to $16.9 \%$ more leaf mass under different treatments than control but the overall leaf yield was only $9.1 \%$ more, the mean difference being non significant. Treatments significantly influenced the leaf mass (p-0.00) and both the nitrogen levels recorded significantly higher yield. $C D$ values show that the yield difference for $N_{1}\left(T_{3}\right)$ treatment (764.2 g) was significantly higher than all other treatments, while for $\mathrm{N}_{2}$ treatment $\mathrm{T}_{4}\left(640 \mathrm{~g} \mathrm{plant}^{-1}\right.$ ) was higher than $\mathrm{T}_{1}$ and $\mathrm{T}_{2}$ treatments (Table 5).

Branch yield

The green branch yield ranged from a minimum of $578.3 \mathrm{~g}$ plant $^{-1}$ under control conditions to a maximum of $1135.3 \mathrm{~g} \mathrm{plant}^{-1}$ in $\mathrm{N}_{2}$ level on CDM. The soil structures did not influence the branch yield. Overall plants on CDM recorded only 5.2\% more branch yield as compared to control. However, all the treatments significantly influenced the branch yield (p-0.00) over control. Maximum branch yield was at $\mathrm{N}_{2}$ level $\left(1034.2 \mathrm{~g}\right.$ plant $\left.^{-1}\right)$ followed by $973.3 \mathrm{~g} \mathrm{plant}^{-1}$ for $\mathrm{N}_{1}$ level, $735.8 \mathrm{~g}$ plant $^{-1}$ for gypsum and $561.7 \mathrm{~g}$ plant $^{-1}$ for control plants. Both the nitrogen levels recorded higher yield compared to control $\left(\mathrm{T}_{1}\right)$ and gypsum only $\left(\mathrm{T}_{2}\right)$ treatments but their difference was not significant (Table 5).

Total yield

A minimum of $1018.3 \mathrm{~g} /$ tree total yield was recorded for $\mathrm{T}_{1}$ treatment in control while the maximum was $1875.3 \mathrm{~g} /$ tree in $\mathrm{N}_{2}$ dose on CDM structure. The soil structures did not influence the total biomass yield; however effect of treatments were positive. Both the nitrogen levels recorded higher total yield compared to $\mathrm{T}_{1}(1034.2 \mathrm{~g})$ and $\mathrm{T}_{2}(1197.5 \mathrm{~g})$ treatments but their difference was not significant (Table 5). 


\section{Root mass}

Fresh root mass ranged from $525 \mathrm{~g}$ plant $^{-1}$ in $\mathrm{T}_{1}$ to $850 \mathrm{~g}$ plant $^{-1}$ under $\mathrm{T}_{3}$ treatment in control plants compared to $341.6 \mathrm{~g} \mathrm{plant}^{-1}$ in $\mathrm{T}_{1}$ to $700 \mathrm{~g} \mathrm{plant}^{-1}$ in $\mathrm{T}_{4}$ treatment on CDM. Mean fresh root mass was $32 \%$ higher under control conditions (729.1 $\mathrm{g}^{-1}$ tree ${ }^{-1}$ as compared to CDM structure $\left(552.5 \mathrm{~g} \mathrm{tree}^{-1}\right)$. The effect was visible in all the treatments.

\section{Number of roots}

Number of roots was divided into two categories: those with $<50 \mathrm{~cm}$ length and with length $>50 \mathrm{~cm}$. Number of roots with $<50 \mathrm{~cm}$ length ranged from 6 to 15 in various treatments under control conditions which are more than the corresponding treatment on CDM. Reverse was true for roots with $<50 \mathrm{~cm}$ length. Smaller roots were thicker resulting in higher root mass for control treatments. Roots get thinner as they penetrated $\mathrm{CaCO}_{3}$ layer.

Performance of shrub species on various types of mound

Results showed that $S$. nudiflora maintained the best survival after 36 months on soil structures (DRM 87.5\% \& CDM 100\%) as well as in control (95.8\%). While CDM was the best structure for A. lentiformis (95.8\%) and DRM for A. stocksii (87.5\%), their performance was poor in control $(21 \%)$.

GLM procedure was applied on the entire data to find out the influence of different soil structures and planting year on overall survival of different plant species during the course of study. It showed that soil structures significantly influenced the survival at p-0.000 (Table-6). LSD values indicated that both the soil structures, CDM (87.9\%) and DRM (82.0\%), recorded significantly higher survival at p- 0.000 as compared to control (43\%), but the survival difference between both the structures was not significant (p-0.099).

Table 6. Periodic \% survival, height $(\mathrm{cm})$ and crown diameter $(\mathrm{cm})$ of plant species on various soil structures at 36 months of age

\begin{tabular}{lccccccccc}
\hline Plant Species & \multicolumn{3}{c}{ \% survival } & \multicolumn{3}{c}{ Height $(\mathrm{cm})$} & \multicolumn{3}{c}{ Crown dia (cm) } \\
& DRM & CDM & Con & DRM & CDM & Con & DRM & CDM & Con \\
\hline S. nudiflora & 87.5 & 100 & 95.8 & 168.1 & 158 & 123 & 141 & 157.0 & 129.1 \\
A. stocksii & 87.5 & 50.0 & 21.0 & 45.7 & 47.3 & 40.8 & 89.6 & 91.0 & 68.0 \\
A.lentiformis & 66.7 & 95.7 & 21.0 & 80.1 & 84.8 & 41.1 & 110 & 113.6 & 82.2 \\
Mean & 80.6 & 82.0 & 45.8 & 98.2 & 96.7 & 68.3 & 113.5 & 120.5 & 93.1 \\
\hline
\end{tabular}

S. nudiflora attained significantly higher height on all the three structures as compared to Atriplex species, A. lentiformis also recorded significantly higher height than A. stocksii on soil structures but there was no difference to control. For crown diameter, S. nudiflora attained maximum values on all the three structures; on soil structures its difference was significant with A.slocksii only (57.4\% \& $72.5 \%$ more on DRM and CDM, respectively). The difference was $28.1 \%$ and $38.2 \%$ on DRM and CDM with A. lentiformis.

\section{Above ground biomass production}

Component wise green and dry above ground biomass yield are summarized in Table 7. Nature of species influenced the biomass yield significantly. Soil structures enhanced the biomass yield for all the species as compared to control but species responded differently to CDM and DRM structures. Two factor ANOVA showed that choice of species and soil 
structures significantly influenced the green and dry biomass yield for leaf, branch and total yield.

Table 7. Component wise Green and Dry Biomass (mean $\pm \mathrm{SE}$ ) yield $\mathrm{g}$ bush $^{-1}$

\begin{tabular}{|c|c|c|c|c|c|c|c|c|}
\hline \multirow[t]{3}{*}{ Plant Species } & \multicolumn{4}{|c|}{ Green } & \multicolumn{4}{|c|}{ Dry } \\
\hline & DRM & CDM & Control & Mean & DRM & CDM & Control & Mean \\
\hline & \multicolumn{8}{|c|}{ Leaves } \\
\hline \multirow[t]{2}{*}{ S. nudiflora } & 4423.3 & 3025.0 & 1458.3 & 2968.9 & 729.0 & 645.0 & 370.0 & 581.3 \\
\hline & $(757.3)$ & (467.9) & (188.4) & & (132.8) & (99.7) & $(47.8))$ & \\
\hline \multirow[t]{2}{*}{ A. stocksii } & 1366.7 & 956.7 & 475.0 & 932.8 & 381.0 & 290.0 & 121.0 & 264.0 \\
\hline & (223.8) & (411.6) & (95.7) & & (62.4) & (124.6) & (24.3) & \\
\hline \multirow[t]{2}{*}{ A. lentiformis } & 1825.0 & 2316.7 & 375.0 & 1505.6 & 416.0 & 593.0 & 92.0 & 367.0 \\
\hline & (114.6) & (196.5) & (155.0) & & $(36.9)$ & $(56.2)$ & $(38.2)$ & \\
\hline \multirow[t]{2}{*}{ Mean } & 2538.3 & 2099.4 & 769.4 & & 509 & 509 & 194 & \\
\hline & \multicolumn{8}{|c|}{ Branches } \\
\hline \multirow[t]{2}{*}{ S. nudiflora } & 2425.0 & 2633.3 & 1083.3 & 2047.2 & 1212.0 & 1379.0 & 615.0 & 1068.7 \\
\hline & (339.4) & (409.6) & $(166.0)$ & & $(169.6))$ & $(214.5)$ & (94.2) & \\
\hline \multirow[t]{2}{*}{ A. stocksii } & 951.7 & 591.7 & 263.3 & 615.6 & 634.0 & 361.0 & 110.0 & 368.3 \\
\hline & (197.0) & (216.7) & (83.9) & & (125.4) & (132.4) & (34.9) & \\
\hline \multirow[t]{2}{*}{ A. lentiformis } & 1444.7 & 1175.0 & 253.3 & 956.7 & 649.0 & 580.0 & 115.0 & 448.0 \\
\hline & $(273.2)$ & $(90.1)$ & $(54.8)$ & & (101.9) & (22.5) & $(24.9)$ & \\
\hline \multirow[t]{2}{*}{ Mean } & 1619.4 & 1466.7 & 533.3 & & 832 & 773 & 280 & \\
\hline & \multicolumn{8}{|c|}{ Total biomass } \\
\hline \multirow[t]{2}{*}{ S. nudiflora } & 6548.3 & 5658.3 & 2541.7 & 4916.1 & 1940.7 & 2024.1(2 & 984.2 & 1649.7 \\
\hline & (950.4) & (759.9) & $(337.1)$ & & $(257.2)$ & 77.9) & $(133.6)$ & \\
\hline \multirow[t]{2}{*}{ A. stocksii } & 2358.3 & 1548.3 & 738.3 & 1548.3 & 1012.5 & 650.9 & 230.4 & 631.3 \\
\hline & $(401.1)$ & $(623.1)$ & (178.9) & & $(180.0)$ & $(254.5)$ & $(180.0)$ & \\
\hline \multirow[t]{2}{*}{ A. lentiformis } & 3266.6 & 3491.7 & 628.3 & 2462.2 & 1094.3 & 1172.8 & 207.4 & 814.8 \\
\hline & (387.7) & $(280.0)$ & (146.7) & & (131.7) & (72.4) & $(38.2)$ & \\
\hline Mean & 4057.8 & 3566.1 & 1302.8 & & 1349.2 & 1282.6 & 473.9 & \\
\hline
\end{tabular}

Leaf yield

S. nudiflora produced maximum mean green leaf mass $(2969.0 \mathrm{~g})$ which was 1.9 and 3.2 times more than A. lentiformis and A. stocksii respectively. However, in case of dry mass the difference was 1.6 and 2.2 times only, succulent nature of $S$. nudiflora resulted in higher green leaf mass accumulation compared to excretory nature of Atriplex spp. Both the soil structures significantly (p- 0.03) enhanced the yield but they were not different with each other. Structure wise DRM recorded maximum mean green leaf mass (2538.3 g) followed by CDM (2099.4 g) and control (769.4g). Both DRM and CDM recorded $509 \mathrm{~g}$ dry weight which was 2.6 times of control (194g). For S. nudiflora and A. stocksii, DRM produced maximum leaf mass but it was CDM for A. lentiformis. Among Atriplex spp., leaf yield for $A$. lentiformis was 2.4 and 1.3 times more than A. stocksii on CDM and DRM, respectively. However in control, A. stocksii recorded 1.2 times more leaf mass $(475.0 \mathrm{~g})$ than $A$. lentiformis $(375.0 \mathrm{~g})$.

Branch yield

Maximum mean green (2047.2 g) and dry (1068.7 g) branch yield was recorded for $S$. nudiflora which was $2.1 \& 2.4$ and $3.3 \& 2.9$ times more than A. lentiformis and A. stocksii. It showed that branch component does not store moisture content. Soil structure enhanced 
branch growth also and all the three species recorded significantly higher branch yield (00$0.01)$ compared to control. DRM recorded maximum branch yield (1619.4 \& 832g) followed by CDM (1466 \& 773.0g) which was 2.7 to 3 times more than control $(533.3 \& 280.0 \mathrm{~g})$. Atriplex spp. recorded more branch mass on DRM but CDM was best for $S$. nudiflora. Here too A. stocksii recorded more branch mass on control than A. lentiformis.

Total yield

Overall S. nudiflora recorded maximum mean green and dry (4916.1 \& $1649.7 \mathrm{~g})$ biomass compared to $2462.2 \& 824.8 \mathrm{~g}$ for A. lentiformis and $1548.3 \& 631.3 \mathrm{~g}$ for A. stocksii. Soil structures significantly enhanced the total biomass as compared to control in all the three species. Among structures for $S$. nudiflora and A. stocksii, DRM accumulated maximum biomass which was 15.7 and $52.3 \%$ than CDM and control. For A. lentiformis, CDM was the best structure and its green biomass yield was $6.9 \%$ more than DRM. Biomass yield was more on soil structure for A. lentiformis but under control conditions A. stocksii performed better.

Overall DRM was the best structure recording $13.8 \%$ and $211.5 \%$ more green biomass as compared to CDM and control respectively. Difference between CDM and control was $173.7 \%$. Control was at third place. Alternatively, S. nudiflora produced maximum dry biomass on all the three structures (2.16 tha ${ }^{-1}$ on DRM, 2.25 tha ${ }^{-1}$ on CDM and 1.09 tha $^{-1}$ on control followed by A. lentiformis (1.18 tha $\mathrm{t}^{-1}$ on DRM, $1.30 \mathrm{tha}^{-1}$ on CDM and $0.23 \mathrm{tha}^{-1}$ on control). A. stocksii produced minimum biomass (1.13 tha $^{-1}$ on DRM, 0.72 tha $^{-1}$ on CDM and 0.26 tha $^{-1}$ on control) among all the three species. Overall DRM was the best planting practice producing maximum mean dry biomass, 1.49 tha $^{-1}$ closely followed by CDM (1.42 tha $^{-1}$ ) while control was poor with 0.53 tha $^{-1}$.

Growth of native vegetation

Growth of salt tolerant native species was encouraged and a number of annuals and grasses appeared gradually. Due to heavy rain in June 2000, a number of plant species appeared in the experimental area. A weed evaluation study performed in September 2000 recorded an average yield of grass of $762 \mathrm{gm}^{-2}$. The dominant species was Sporobolus helvolus $\left(1217 \mathrm{~g} . \mathrm{m}^{-2}\right)$ followed by Dactyloctenium sindicum (800 g.m $\left.{ }^{-2}\right)$, Sueda fruiticosa $\left(600 \mathrm{~g} . \mathrm{m}^{-2}\right)$ and Trienthema triquetra. Very meagre rainfall was recorded in the year 2002 and the weed evaluation study performed in October 2002 indicated that only 6 plant species (Sporobolus sp., Cenchrus sp., Sueda fruiticosa, Cyperus sp., Dactyloctenium sindicum. and Pulicaria crispa) appeared that year. Sporobolus sp. was the most dominant plant species producing $58 \mathrm{~g} . \mathrm{m}^{-2}$ dry biomass in the inter row spaces in the severe drought year, followed by Cenchrus sp. $\left(25 \mathrm{~g} . \mathrm{m}^{-2}\right)$. Weed evaluation was done in September 2006 and mean green weed yield of $55 \mathrm{~g} \mathrm{~m}^{-2}$ was obtained. It was mainly dominated by halophyte grass species Sporobolous spp and Chloris spp. In September 2008, green weed biomass yield ranging from $100 \mathrm{~g}$ to $550 \mathrm{~g}$ $\mathrm{m}^{-2}$ was obtained in various quadrats throughout the experimental area. Highest frequency was observed for Chloris virgata but greenmass range was from $150-250 \mathrm{~g} \mathrm{~m}^{-2}$ followed by Sporobolus diander ( 275-500 $\mathrm{g} \mathrm{m}^{-2}$ ) and Dactyloctenium aegypticum (100-250 $\mathrm{g} \mathrm{m}^{-2}$ ). Other halophytic species present were Sueada fruiticosa, Trienthema triquetra, Cressa cretica and Sesuvium sesuviodes but their green mass was not significant. 
Natural germination of $S$. persica was observed under the canopy of $P$. Juliflora. The process still continues and now after 18 years existing seedlings have grown as mature trees suppressing the growth of $P$. juliflora.

It is possible to make wastelands productive by adopting site-specific technologies. Halophytes performed better than glycophytes. S. persica (Arya et al. $2005 \& 2014$ ) and $S$. nudiflora (Arya 2005) were the best tree species among the indigenous plant species while $C$. mopane was the best exotic species. C. mopane proved to be an ideal species for salty waste lands with $89.3 \%$ overall mean survival after five years of establishment. Among the indigenous halophytes taken from different agro-climatic zone (coastal region), S.nudiflora adapted well to the dry land stress conditions. It was the best species by virtue of nearly $100 \%$ survival, maximum growth and biomass in all the three planting treatments followed by A. lentiformis. Shrubs of genus Atriplex have the potential to produce nitrogen rich fodder from highly degraded arid salt affected soils. High ash content $(\sim 40 \%)$ requires its mixing with cereal residues (Arya 2009; Arya 2013).

Large pit size was necessary to mix amendments to create less salty environment during seedling establishment. Double ridged and Circular dish mounds enhanced survival of all the plant spp. by providing protection from water-logging and less salty environment. Crescent shaped drainage trenches served dual purpose, helped in leaching of salts and harvesting of water. Improvement in soil status, substantial reduction in soil $\mathrm{pH}$ and electrical conductivity and improvement in percent organic carbon content during the study period was observed. Plantation activities promoted the natural regeneration and number of plant species increased gradually.

Production from non-productive salt affected soils is necessary to cater the food, forage, timber, fuel wood, oil-seed, medicine and other minor products demands of ever increasing human and cattle population. Since water is the most limiting factor in reclaiming these wastelands, intensive research on water harvesting and use of saline/sodic water is needed as water is the most limiting factor for afforestation of these soils. Research should also focus on search for locally available cheaper amendments to lower the cost of reclamation. Many halophytes produce higher biomass with minimum management from the soils with high level of management, even commercial forestry is feasible. Arid zone economy is livestock based but due to increasing human pressure even marginal lands are being used for agriculture. Adopting bio saline agroforestry, the nomadic behaviour of large population may be checked in dry regions.

\section{Acknowledgement}

The authors sincerely thank the Director, AFRI for providing all necessary facilities during the study period.

\section{References}

Arya R, Chaudhary KR \& Lohara RR 2005. Effect of Nitrogen and gypsum on establishment and early growth of Salvadora persica (L.) in a salt affected soil in hot arid zone. Forest Trees and Livlihood, 15:291-306. 
Arya R \& Lohara RR. 200. Studies on mound practices for establishment and growth of various plant species on saline and waterlogged soil in hot arid zone. Indian Forester, 132(5): 556-564.

Arya R. 2009. Performance of Atriplex spp. on various soil structures on arid affected soil in Rajasthan. Current Agriculture, 33: 1-7.

Arya R. 2013 Managing Degraded Arid Sandy Salt affected Soils with Atriplex sp for improved Productivity. In: Proceedings of First Indian Forest Congress held at New Delhi during 9-11 March, 2011. ICFRE, Dehradun, pp 93-99.

Arya R, Lohara RR \& Meena RL. 2014. Survival and biomass production of Salvadora persica on various types of salt affected soils under arid conditions in Rajasthan and Gujarat. Annals of Arid Zone, 53 (1): 43-49.

Amonkar DV \& Karmakar SM. 1978. Ion regulation in Salvadora persica. Journal of Biological Science, 21: 13-18.

Bennet JG. 1983. A field guide to soil and site description in Zimbabwe. Technical Hand Book No. 6 Government Printer, Zimbabwe.pp: 60 .

Lock JM. 1989. Legumes of Africa: a check-list. Royal Botanic Gardens, Kew. 619 pp. .

Motlhanka DM. 2008. Free radical scavenging activity of selected medicinal plants of Eastern Bostwana. Pak. J. Biol. Sci, 11(5):805-808.

Pasternak D, Aronson J A, Ben-Dov J, Forti M, Mendlinger S, Nerd A \& Sitton D. 1986. Development of new arid zone crops for the Negev of Israel. Journal of Arid Environments, 11:37-59.

Sharma RC, Rao BRM and Saxena RK. 2004. Salt affected soils in India- Current assessment. In "Advances in Sodic Land Reclamation" International Conference on Sustainable Management of Sodic Lands (U. P. Council of Agricultural Research, Lucknow, pp: 1-26.

Uchiyama Y. 1987. Salt tolerance of Atriplex nummularia. Technical Bulletin of the Tropical Agricultural Research Center No 22. Tropical Agricultural Research Center, Yatabe, Tsukuba, Ibaraki, Japan, pp:69 . 